\title{
Berebut Wacana: Hilangnya Etika Komunikasi di Ruang Publik Dunia Maya
}

\author{
Saiful Mustofa \\ Institut Agama Islam Negeri Tulungagung, Jawa Timur, 66221, Indonesia \\ sayfulmuztofa@gmail.com
}

\begin{abstract}
ARTICLE INFO
Article history:

Received : 2019-01-30

Revised : 2019-04-02

Accepted : 2019-05-23
\end{abstract}

Keywords:

Communication Ethics

Hoax

Public Sphere

\section{ABSTRACT}

The background of this study concern to phenomenon a communication ethics no longer exist in the social media public sphere. Social media, as one of the products of the digital revolution being a free stage to spread anxiety; ethnic, racial, and religious sentiments (SARA) to the legitimacy of the authority of truth. By using critical hermeneutic approach of Jürgen Habermas, this paper attempts to examine the phenomenon of discourse struggle which is dominated by hate speech in religion and hoax on social media for the period 2017-2018 which on average loses communication ethics. The struggle for discourse in social media public sphere shows the existence of strong political penetration by utilizing religious symbols as "weapons" so that the consensus on mutual understanding does not occur.

\section{ABSTRAK}

Artikel ini berangkat dari fenomena betapa etika komunikasi Etika Komunikasi Berita palsu Ruang Publik

seakan sudah tak berlaku lagi dalam ruang publik dunia maya. Media sosial-sebagai salah satu produk revolusi digital-menjadi panggung bebas untuk menebar kecemasan, narasi-narasi kebencian berbalut SARA dan legitimasi otoritas kebenaran. Dengan menggunakan kacamata hermeneutika kritis Jürgen Habermas, artikel ini ingin mengkaji fenomena perebutan wacana yang didominasi dengan narasi kebencian (hate speech) berbalut agama dan hoaks di media sosial periode 2017-2018 yang rata-rata kehilangan etika komunikasi. Perebutan wacana dalam ruang publik dunia maya menunjukkan adanya penetrasi politik yang kuat dengan memanfaatkan simbol-simbol keagamaan sebagai "senjatanya" sehingga konsensus saling memahami tidak terjadi lagi.

Copyright $@ 2019$ IAIN Palangka Raya.

All rights reserved.

\section{Pendahuluan}

Dalam konteks ruang publik (public sphere), perebutan wacana sesungguhnya merupakan suatu hal yang lazim. Seiring dengan munculnya era disrupsi maka perebutan wacana di ruang publik pun seolah mengalami pergeseran; dari dunia nyata ke dunia maya. Dunia maya atau virtual pun pada akhirnya menjadi panggung kontestasi bahkan "perang" antara wacana dominan untuk menentukan siapa yang paling berpengaruh dan punya validitas klaim kebenaran.

Semenjak Pilpres 2014, perebutan wacana atau istilah yang lebih ekstrem adalah "perang wacana" dalam konteks politik- 
kekuasaan, mengalami peningkatan yang signifikan. Model kampanye yang sebelumnya konvensional berubah menjadi digital. Dengan memanfaatkan kecanggihan dunia maya, masing-masing kubu menggunakan black campaign dengan amunisi politik identitas berbau SARA; hoaks, hate speech secara terstruktur dan masif seperti jamur di musim hujan yang tumbuh subur di berbagai media sosial.

Pergulatan wacana Islam pun juga mengalami dampaknya. Baik pendukung Jokowi-JK dan Prabowo-Hatta menggunakan simbol-simbol agama untuk mencari simpati, legitimasi sekaligus de-legitimasi lawannya. Head-to-head antarkedua kandidat presiden itupun berlangsung dramatis. Dengan memanfaatkan media (online) termasuk media sosial, kedua kubu menjadikan dunia maya sebagai arena tempur baru dan propaganda. Ada media yang resmi dibuat untuk mendukung masing-masing calon, sebaliknya tidak sedikit pula yang abal-abal. Beberapa di. antaranya adalah, inilah.com, SelamatkanIndonesia.org,PrabowoSubianto.i nfo, PKS.or.id, PKSPiyungan.org, suaraNews.com, Voa-Islam.com, Obor Rakyat, DakwahTuna.com, Petikan.com, Info-IndonesiaKita.com, IntrikNews.com. LaskarJokowi.com, Jokowi.id dan masih banyak lagi (14).

Pada 17 April 2019, pesta demokrasi Pileg dan Pilpres secara serentak dihelat kembali. Meningkatnya suhu politik pun sudah terasa selama tahun 2017. Peristiwa besar yang salah satunya dimulai dari Aksi Bela Agama 211, 212 atas tindakan Basuki Tjahaja Purnama (Ahok) lantaran menistakan Surat Al-Maidah ayat 51 sampai yang terbaru pembakaran bendera HTI oleh anggota Banser NU dalam momen peringatan Hari Santri Nasional (HSN) 2018 di Garut, Jawa Barat terus bergulir. Hal demikian telah menimbulkan sejumlah ironi yang salah satunya hilangnya etika komunikasi dalam publik dunia maya karena didominasi dengan hoaks dan ujaran kebencian.

Di samping itu, sejauh pelacakan penulis belum banyak penelitian yang mengulas tentang fenomena hilangnya etika komunikasi di ruang publik dunia maya khususnya media sosial. Apalagi menggunakan pendekatan etika diskurus Habermas.
Kendati demikian, ada beberapa studi terdahulu yang mengulas tema hampir serupa terutama mengenai mediatisasi agama di ruang publik dan hoaks dengan memanfaatkan agama sebagai komodifikasinya.

Pertama, José Casanova jauh-jauh hari juga pernah menyuguhkan tesis perihal agama di ruang publik atau deprivatisasi agama sebagai tren global yang terjadi di semua agama seluruh dunia. Agama di ruang publik menurutnya adalah agama yang mencoba mengasumsikan atau mengambil karakter, fungsi, dan peran di publik. Dalam konteks ini dikotomi antara yang "privat" dan "publik" seolah melebur atau setidaknya bukan lagi menjadi masalah yang serius. Dengan menggunakan perbedaan analitis antara tiga bidang pemerintahan modern: negara, politik dan sipil, orang dapat membedakan tiga jenis agama di ruang publik yang sesuai dengan ketiga bidang ini. Dalam ranah politik misalnya, agama dapat memobilisasi sumber daya kelembagaan mereka untuk berkompetisi melalui partai politik, gerakan sosial, atau agen-agen lobi di tingkatan masyarakat politik. Sedangkan agama ruang publik di tingkat masyarakat sipil akan dicontohkan oleh agama-agama yang memasuki ranah publik; ruang publik masyarakat sipil yang tidak dibedakan, untuk bersama-sama berpartisipasi dalam debat publik terbuka tentang res publica; tentang masalah publik, kebijakan publik dan kebaikan bersama (7).

Kedua, yang paling mutakhir adalah buku hasil penelitian Moh. Yasir Alimi yang dengan sangat komprehensif merekam sekaligus menganalisis fenomena mediatiasasi agama yang akhir-akhir ini terjadi di jagat dunia maya.

Penelitian ini boleh dibilang semacam etalase yang merekam lengkap semua fenomena keberagaaman itu dari perspektif sosiologi agama dalam konteks revolusi digital. Perkawinan kedua hal itu disebutnya sebagai "mediatization of religion" atau fenomena kebudayaan di mana ekspresi keagamaan dilakukan melalui internet dan media online (4).

Alimi merekam setiap jejak digital baik di medsos (Facebook, Twitter, Whatsapp) dan portal online yang acapkali mendengungkan 
isu-isu sektarianisme agama, hoaks dan "perang tagar": \#aksi bela ulama\#kriminalisasi ulama\#aksi bela tauhid\#2019 ganti presiden\# dalam konteks framing media. Bedanya penelitian ini tidak menggunakan pendekatan etika diskurus dan hermenutika kritis yang menjadi salah ciri dari konsepsi pemikiran Habermas.

\section{Metode Penelitian}

Jenis penelitian ini secara umum adalah penelitian kualitatif. Namun karena tidak mengharuskan peneliti terjun ke lapangan dan hanya mengkaji media serta literatur maka penelitian ini masuk dalam kategori library research. Secara umum library research adalah penelitian yang menggunakan literatur, baik berupa buku, catatan maupun laporan hasil penelitian terdahulu (13).

Sedangkan untuk pendekatan, penelitian ini menggunakan hermeneutika kritis Habermas. Penelitian dalam tradisi kritis, menyitir pendapat Kincheloe dan McLaren, mengambil bentuk kritik kesadaran dirikritik kesadaran diri yang dimaksud bahwa para peneliti berusaha untuk menjadi sadar atas berbagai tuntutan ideologis dan praanggapan epistemologis yang menjiwai penelitian mereka sekaligus klaim-klaim acuan yang berciri subyektif, intersubyektif, dan normatif. Dengan kata lain, para peneliti kritis masuk dalam penelitian tanpa direpotkan oleh asumsi-asumsi mereka sehingga tak seorang peneliti pun dibingungkan terkait dengan beban epistemologis dan politis yang mereka bawa ke tempat penelitian (17).

Lebih jauh, menurut F. Budi Hardiman hermeneutika kritis adalah sebuah metode ilmiah yang digunakan untuk memahami struktur-struktur makna atau teks yang terungkap dalam tuturan; hasil dari suatu proses komunikasi yang terdistorsi. Dalam hal ini, Habermas menyebut ada dua hal dalam batasan ini yang perlu dijelaskan: metode ilmiah dan teks yang terdistorsi. Pertama, Habermas-setidaknya dalam usia mudanya-kembali pada Dilthey dengan mengkhususkan kembali hermeneutik sebagai metode ilmiah. Ada tipe metode ilmiah yang digunakan untuk menjalankan hermeneutika kritis: psikoanalisis Freud dan kritik ideologi Marx. Kedua, baik psikoanalisis maupun kritik ideologi menghadapi suatu teks yang tidak lazim karena susunan-susunan makna yang tertulis di sana merupakan hasil distorsi sistematis yang bahkan tidak disadari oleh penulisnya sendiri (12).

Dengan demikian, artikel ini ingin menyuguhkan hilangnya etika komunikasi ruang publik dalam pengertian politis (political public sphere) dunia maya, khususnya dalam pergulatan wacana politikIslam kurun waktu 2017-2018. Penulis sengaja tidak membatasi artikel ini secara spesifik merujuk kepada media sosial apa, hanya saja karena keterbatasan ruang, artikel ini hanya akan terfokus pada peristiwaperistiwa skala besar yang membentuk metanarasi baru cara pandang keberagamaan di Indonesia. Ditambah lagi, penelitian sosial media tidak hanya memperhatikan perannya saja tetetapi juga teks, video dan gambar visual.

\section{Hasil dan Pembahasan}

\section{a. Kerangka Etika Diskursus dalam Media Sosial}

Etika diskursus merupakan terminologi yang tak asing lagi dalam filsafat Jerman. Secara epistemolgi berakar pada etika Kant yang kemudian dielaborasi oleh generasi kedua Mazhab Frankfrut, Habermas.

Untuk menemukan sebuah kebenaran melalui penalaran, manusia senantiasa membutuhkan semua akses informasi dan gagasan. Jika manusia tetap berpegang teguh pada logikanya, kebenaran akan muncul melalui pergulatan informasi dan gagasan. Maka perubahan sosial tidak akan terjadi melalui kekerasan, melainkan muncul melalui proses diskusi dan persuasi (23).

Lebih dari itu, dalam konteks ini, titik tekan yang harus dipahami terletak pada diskursus. Menurut Hardiman, diskursus Habermas bertujuan untuk mencapai sebuah konsensus intersubyektif melalui percakapanpercakapan (baik verbal maupun literal). Namun sementara konsensus pada tindakan komunikatif sudah diterima secara spontan dan dipakai oleh para peserta komunikasi tanpa pikir panjang lagi, para peserta diskursus kali ini harus menghasilkan konsensus lagi, tetetapi pada taraf yang reflektif. Sebab diskursus adalah bentuk 
refleksi dari tindakan komunikatif. Artinya, diskurus adalah kelanjutan tindakan komunikatif dengan memakai sarana lain: argumentatif. Dengan demikian, dapat dikatakan bahwa diskursus menandai bentuk komunikasi modern di mana orang tidak begitu saja menerima sesuatu dengan pemahaman-pemahaman yang berkembang, melainkan menguji hal itu dengan pertimbangan rasional. Pendek kata, diskursus merupakan bentuk komunikasi yang bersifat kritis dan terbuka. Dan refleksi diri membutuhkan perpaduan antara rasio dan kepentingan emansipatoris atau mensyaratkan adanya rasionalitas komunikatif (10).

Rasionalitas komunikatif adalah salah satu prasyarat wajib ada jika ingin mendambakan pola "komunikasi yang sehat". Yang penulis maksud komunikasi sehat adalah komunikasi yang berorientasi pada konsensus untuk saling memahami. Untuk mencapai kesepakatan itu, setiap rasionalitas yang melekat dalam praktik tindakan komunikatif harus didasarkan pada alasan. Dalam bahasa yang lebih jelas, rasionalitas orang-orang yang berpartisipasi dalam praktik komunikatif ini-baik di dunia nyata atau maya - ditentukan oleh apakah mereka bisa, dalam keadaan yang sesuai, memberikan alasan atas apa yang mereka katakan atau diakui secara intersubyektif (24).

Dengan demikian, jika ada media sosial entah akun atas nama individu atau kelompok tertentu yang menyuguhkan ungkapan tanpa adanya alasan-alasan yang rasional maka ia membiarkan terjadinya kematian rasionalitas komunikatif atau hilangnya etika komunikasi.

Lebih dari itu, dalam rangka mewujudkan ruang dialogis dan konsensus saling memahami itu, klaim-klaim kesahihan (validity claims) harus dipenuhi. Kalau kita sepakat tentang dunia alamiah dan obyektif, kita mencapai "klaim kebenaran". Kalau sepakat dengan pelaksanaan norma-norma dalam dunia sosial, kita mencapai "klaim ketepatan". Kalau kita sepakat tentang kesesuaian antara dunia batiniah dan ekspresi seseorang, kita mencapai "klaim autentisitas atau kejujuran". Akhirnya kalau kita bisa menjelaskan macam-macam klaim itu dan mencapai kesepakatan, kita mencapai "klaim komprehensibilitas". Setiap komunikasi yang efektif harus mencapai keempat klaim ini, dan orang yang mampu berkomunikasi dalam arti menghasilkan klaim-klaim itu, disebut mempunyai "kompetensi komunikatif" (11).

Dalam bahasa yang lebih sederhana, Franz Magnis-Suseno menyebut bahwa begitu seseorang masuk dalam sebuah pembicaraan dengan sendirinya ia mengajukan empat klaim: pembicaraannya jelas, benar, jujur dan betul. "Jelas" artinya ia mengklaim bahwa bisa mengungkapkan dengan tepat apa yang ia maksud. "Benar" yakni bahwa apa yang ia katakan adalah apa yang mau ia ungkapkan. "Jujur" artinya bahwa ia tidak bohong. "Betul", yaitu bahwa apa yang ia katakan itu wajar dikatakan. Sekaligus, dengan mengatakan sesuatu, ia secara implisit juga menyatakan diri bersedia untuk membuktikan kebenaran empat klaim itu dalam sebuah diskursus. Jadi meskipun komunikasi dalam kenyataan sering gagal, namun setiap orang yang berbicara memiliki idea tentang komunikasi yang berhasil. Ia selalu sudah tahu apa itu rasionalitas komunikatif (9).

Untuk lebih jelasnya silakan lihat ilustrasi pada gambar di bawah ini.

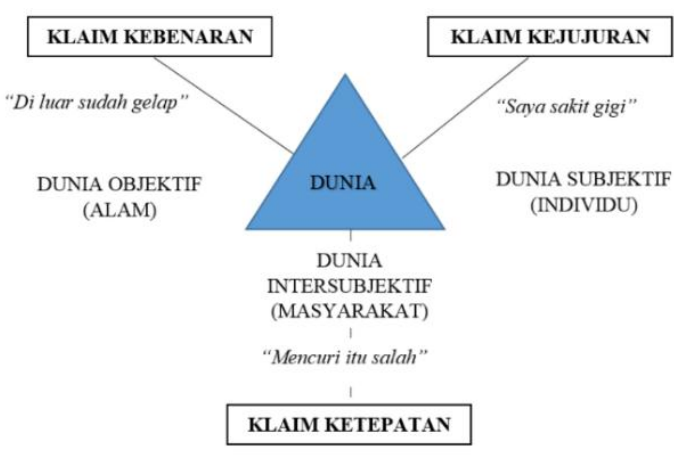

Dalam komunikasi diambil tiga macam sikap performatif terhadap dunia. Konsensus dapat tercapai jika ketiga klaim kesahihan itu serentak dipenuhi (10).

\section{b. Fenomena Hoaks, Hate Speech Komodifikasi Agama}

Hoaks atau berita palsu adalah istilah baru yang belum lama menggejala di jagat dunia maya. Secara terminologi, hoaks adalah penyebaran berita melalui media sosial yang dirancang sebaik-baiknya sehingga tampak seperti nyata. Tujuannya adalah untuk memengaruhi atau 
memanipulasi pendapat pengguna media sosial pada topik tertentu untuk tujuan tertentu (21).

Masyarakat Telematika (Mastel) pada tahun 2017 melakukan survei tentang "Wabah Hoaks" yang hasilnya menyebutkan bahwa saluran yang paling banyak digunakan dalam penyebaran hoaks adalah media sosial (Facebook, Twitter, Instagram, Path) yang mencapai 92,40 persen, disusul oleh aplikasi chatting (Whatsapp, Line, Telegram) sebanyak 62,80 persen dan melalui situs web sebanyak 34,90 persen. Adapun jenis hoaks yang paling banyak diterima masyarakat adalah masalah sosial-politik, yakni sebanyak 91,80 persen, SARA sebanyak 88,60 persen dan kesehatan sebanyak 41,30 persen. Sementara itu, data yang dipaparkan oleh Kementerian Komunikasi dan Informatika menyebut bahwa terdapat 800 ribu situs di Indonesia yang terindikasi menyebarkan berita palsu dan ujaran kebencian (16).

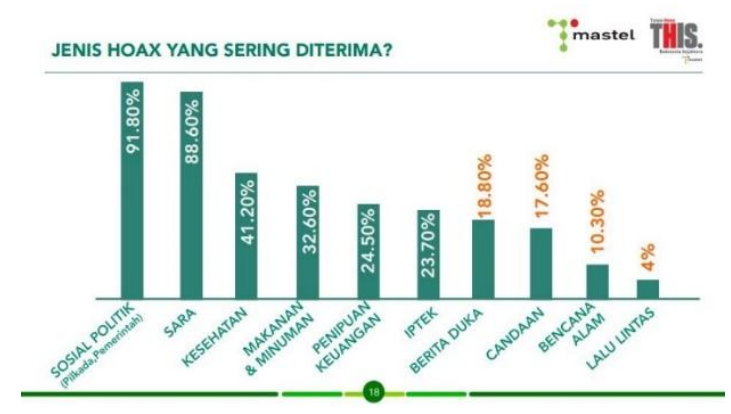

Selain itu, berdasarkan hasil survey yang dilakukan oleh APJII, seperti yang dikutip Yanti Dwi Astuti, jumlah pengguna internet di Indonesia pada tahun 2016 sebesar $51,5 \%$ atau sebanyak 132,7 juta jiwa dari total jumlah penduduk Indonesia sebesar 252,6 juta jiwa. Pengguna internet terbanyak ada di Pulau Jawa dengan jumlah pengguna sebesar 86.339.350 pengguna atau sekitar $65 \%$ dari total pengguna di Indonesia. Pengguna internet pada umumnya didominasi jenis kelamin laki-laki, yaitu sebanyak 52,5\% dan perempuan sebesar $47,5 \%$ dari total pengguna internet di Indonesia(6).

Hasil survei tersebut membuktikan bahwa pengguna internet yang dinilai dari segi usia didominasi oleh usia remaja: umur 20-24 tahun. Remaja pada usia inilah yang saat ini dikenal dengan generasi digital native atau generasi $\mathrm{Z}$ yang menurut William J. Schroer di socialmarketing.com merupakan generasi yang lahir tahun 1995-2012. Teknologi Internet ibarat dua mata pedang yang berbeda, di satu sisi dapat memberikan manfaat yang positif namun di satu sisi dapat pula memberikan pengaruh yang negatif manakala kita tidak dapat menggunakannya dengan baik.

Ketika era digital tiba, semua menjadi lebih mudah, murah, dan cepat. Media sosial telah mengubah cara orang berkomunikasi dan berinteraksi. Pemerintah tak mampu membendung kebebasan berpendapat dan berekspresi dari warganya. Sebab menurut Marshall McLuhan-ahli komunikasi Kanada sebagaimana dikutip oleh Jakob Oetama-media adalah the extension of men, kepanjangan tangan manusia, dan lewat itulah manusia bisa berkomunikasi (22).

Keunggulan utama medsos dibandingkan dengan teknologi lainnya adalah hiperaktualitas dan interaktivitas. Teknologi informasi menjadi semakin terjangkau sehingga hampir semua orang memilikinya. Dunia digital membuat semua media bisa disampaikan baik berupa suara, tulisan, simbol, tulisan, hingga video bisa diunggah untuk dibagikan kepada orang lain. Media ini dengan cepat dapat menyebarkan berita atau peristiwa untuk dikomentari, didiskusikan, ditindaklanjuti, atau disebarkan kembali melalui media lain seperti media cetak, radio, dan televisi. Media digital tidak mengenal batas wilayah, waktu, dan tempat. Fenomena ini sudah diramalkan oleh McLuhan pada 1962 melalui karyanya The Gutenberg Galaxy, bahwa suatu saat dunia ini akan mengalami ketergantungan terhadap teknologi dan menghubungkan dunia dan menjadi sebuah desa global (global village). Orang tak lagi berinteraksi sosial dengan orang lain secara langsung tetetapi melalui media gawai. Komunikasi dilakukan secara cepat dan masal berdasarkan faktor kesamaan pandangan hidup, hobi, strata sosial, hingga agama. Hingga lahirlah interaksi digital yang terkotak-kotak. Media baru ini sudah telanjur dianggap sebagai media yang fleksibel dan bebas sensor. Masyarakat bebas menuliskan apa saja di dalamnya baik itu informasi valid yang bermanfaat maupun informasi hoaks, unek-unek dan sumpah serapah. Selain itu, banyak sekali ditemukan kasus-kasus yang 
tidak diinginkan turut terjadi dewasa ini, mulai dari cyberbullying, dan cybercrime. Mereka beraktivitas di dunia digital dengan memprihatinkan, seperti contoh kasus ketika pemilihan Gubernur di Jakarta yang sempat memperkeruh suasana di media sosial hanya karena ucapannya tentang Surat Al-Maidah ayat 51 dipolitisir sehingga menjadi kasus penistaan agama dan aksi massa. Dengan demikian seperti yang dikutip Alimi, public sphere berubah menjadi "public sphericules" yaitu opini yang dibagikan secara daring meningkatkan ekstremisme, permusuhan dan sikap partisan.

Berbagai ujaran kemarahan yang didasari oleh emosi dalam istilah yang lain dapat digambarkan sebagai extreme speech. Suatu ujaran kemarahan tersebut berlangsung dengan sangat ekstrem dan tajam hingga menstimulasi suatu gerakan sosial. Mengacu pada Pohjonen dan Udupa-sebagaimana dikutip oleh Iswandi Syahputra - berbagai extreme speech tidak hanya terjadi di Indonesia, tetapi juga di India dan Ethopia. Dalam kasus aksi massa berbau agama beberapa tahun terakhir di Indonesia, awalnya juga dipicu secara virtual di media sosial yang disampaikan secara massif dan meluas menjadi aksi massa karena menyangkut agama sebagai identitas religius masyarakat setempat (25).

Baik hoaks maupun hate speech termasuk dalam cybercrime. Hal demikian ditegaskan oleh Kominfo sebagaimana tercantum dalam KUHP, Undang-Undang No.11 Tahun 2008 tentang Informasi dan Transaksi Elektronik (ITE), Undang-Undang No.40 Tahun 2008 tentang Penghapusan Diskriminasi Ras dan Etnis, serta tindakan ketika ujaran kebencian telah menyebabkan terjadinya konflik sosial. Ujaran kebencian ini meliputi penghinaan, pencemaran nama baik, penistaan, perbuatan tidak menenangkan, memprovokasi, menghasut, dan penyebaran berita bohong. Yang dapat dilakukan dalam bentuk orasi kampanye, spanduk, jejaring media sosial, penyampaian pendapat di muka umum, ceramah keagamaan, media massa cetak maupun elektronik, sampai pamflet. Dengan sangsi enam tahun penjara atau denda sebesar satu miliar rupiah $(18,29)$.
Kebijakan di atas ibarat buah simalakama, di satu sisi baik untuk dijadikan rambu-rambu dalam berinteraksi sosial namun di sisi lain juga betabrakan dengan asas kebebasan berekspresi, berbicara dan berpendapat.

Selain itu, fenomena komodifikasi agama sebetulnya bukanlah sesuatu yang baru. Di era post-sekuler, alih-alih lenyap agama justru tampil di ruang publik (public sphere). Era ini adalah tanda berakhirnya dominasi sekulerisme Barat. Sehingga dalam konteks Indonesia, agama adalah topik nomor satu yang disukai warganet di media sosial.

Komodifikasi agama merupakan konstruksi historis dan kultural yang kompleks, sekalipun demikian ciri komersial mereka begitu nyata. Mereka direproduksi dalam konteks kebudayaan tertentu dan kemudian mempersyaratkan kerangka kultural untuk mempertegas signifikansi simbolik dan sosio-ekonomi mereka. Komodifikasi merupakan sebuah proses yang benar-benar diciptakan dan disertakan dalam saluran ekonomi pasar lokal-global dan ledakan agama postmodern. Komodifikasi memang tidak bertujuan memproduksi bentuk dan gerakan agama baru yang berlawanan dengan keyakinan dan praktik agama sebelumnya namun komodifikasi akan mendudukkan agama sebagai barang yang melaluinya fungsi spiritual agama menjadi komoditas yang layak dikonsumsi dalam masyarakat (8).

Dalam konteks Indonesia kontemporer, komodifikasi agama lebih dominan merambat ke ranah ruang publik politik. Penggunaan simbol-simbol atau atribut keagamaan lengkap dengan jargon SARA menjadi bagian yang membanjiri ruang publik. Narasi-narasi tentang Islam melarang pemimpin non-Muslim, kafir dan lainnya kembali menyeruak dalam tahuntahun politik dan itu menjadi isu yang paling efektif untuk "diperjualbelikan".

Politik dan agama memang dua hal yang sulit dipisahkan. Keduanya selalu memainkan peran tersendiri dan saling berjalin-kelindan. Menurut George Moyser, sangat sulit di dunia modern mengabaikan kehadiran agama dalam ruang publik. Hampir setiap hari, sebagaimana ditunjukkan 
oleh media, baik secara individu maupun kelembagaan, kehadiran agama dalam ruang publik memiliki relevansi penting yang berkelanjutan dengan dunia politik (20).

Beberapa tokoh, menyebut fenomena demikian sebagai (Post-)Islamisme; gerakan sosial-politik gaya baru yang coba merevisi konsepsi "Islamisme" tentang kemungkinan terbentuknya negara Islam baik secara teori maupun praktik. Gerakan ini muncul sebagai alternatif atas kebuntuan ideologis dan politis Islamisme sehingga kesan yang tampak adalah adaptif dengan politik modern, seperti demokrasi.

Oleh karena itu, munculnya Islam dalam ruang publik-dengan mengusung komodifikasi agama sebagai - telah menjadi kontestasi di mana para aktivisnya yang militan melahirkan tantangan ke depan dalam praktik dan otoritas interpretatif tradisional untuk berbicara tentang Islam, terutama mengartikulasikan kepentingan sosial dan agenda politiknya. Sebagaimana riset-riset terdahulu (Baso, 1999; Effendy 1998; Farhi, 2001; Hefner 2000; Maarif 1985; Noer, 1996), kontestasi itu terjadi antara kelompokkelompok yang ingin menunjukkan Islam secara kaffah, penekanan dimensi substantif Islam, dan mereka yang ingin meniadakan kehadiran Islam di ruang publik.

\section{c. Embrio Radikalisme Agama di Dunia Maya}

Radikalisme agama merupakan bagian tak terpisahkan dari setiap agama yang ada di dunia, termasuk Islam. Secara terminologi, radikalisme agama merupakan proses mengadopsi atau mempromosikan keyakinan yang ekstrem dan mendorong lahirnya kekerasan untuk mencapai tujuan sosial, politik dan keagamaan (2).

Dalam konteks Indonesia, geliat radikalisme agama mempunyai akar sejarah yang cukup panjang. Amin Abdullah menjelaskan bahwa istilah radikalisme atau sering juga disebut fundamentalisme sebenarnya bukan sesuatu yang baru dan pada dasarnya merupakan gerakan politik yang diselubungi oleh keyakinan agama. Kaum minoritas merasa ditindas, dihegemoni dan ditekan oleh kelompok mayoritas. Tidak ada power sharing (pembagian kekuasaan) di antara mayoritas-minoritas. Dan pluralisme- multikulturalisme tidak pernah bersemai di situ. Masing-masing bertahan dengan kelompok mereka sendiri. Golongan mayoritas mempertahankan status quo tanpa memperhatikan dan mempedulikan hak-hak minoritas. Yang mayoritas ingin menguasai segalanya, dari hulu sampai hilir, sedangkan yang minoritas karena tidak mempunyai akses apa pun dalam wilayah politik, ekonomi, maupun sosial akhirnya mereka berbuat nekat dengan misalnya, meledakan bom di tempat-tempat kaum mayoritas. Bahkan tidak menutup kemungkinan golongan mayoritas sendiri yang meledakan bom itu untuk melanggengkan status quo mereka. Hubungan yang menyangkut kekuasaan dan bermuatan kekerasan ini tidak hanya berlaku bagi hubungan Barat dengan Timur atau Barat dengan Islam (clash of civilization), tetetapi juga berlaku dalam hubungan satu atap kelompok agama sendiri (clash within civilization) di kalangan umat Islam, Protestan dan seterusnya (1).

Secara historis gerakan ini diawali oleh dari munculnya gerakan Padri di Sumatera Barat pada awal abad ke-19. Menurut Christine Dobbin — seperti yang dikutip Saiful Umam - awalnya gerakan ini diinisiasi oleh tiga pemuda Muslim yang baru pulang haji pada tahun 1803, setelah Wahabi merebut Mekkah dan Madinah. Mereka lantas meniru model gerakan Wahabi untuk membangkitkan kembali praktik keagamaan di Sumatera Barat. Konflik antara Kaum Padri dan Kaum Adat pun tak terelakkan, dan ketika Kaum Adat sudah terdesak mereka meminta bantuan kepada Belanda untuk membantunya mendapatkan kembali kedaulatan atas wilayah tersebut. Gerakan Padri akhirnya kocar-kacir oleh gempuran militer Belanda dan pada tahun 1938, perang saudara itupun selesai (26).

Kemudian, pada dasawarsa awal abad ke-20, muncul dua organisasi Islam yang menyebarkan paham radikal: Al-Irshad dan Persis. Al-Irshad (Jam'iyyat al-Islah wa alIrshad) didirikan oleh seorang pemuka agama dari Sunda, Ahmad Surkati pada tahun 1915. Tujuan utamanya adalah untuk memperbarui praktik keagamaan, khususnya di lingkungan komunitas Arab di Indonesia berdasarkan al-Qur'an dan hadis. Di samping itu, mereka juga mengadvokasi hak-hak 
perlakuan yang sama di antara sesama orang Arab.

Setelah merdeka, muncul benih-benih radikal baru yang ingin memberontak dan mendirikan negara di bawah panji Islam. Adalah Kartosuwiryo (1905-1962), seorang yang kecewa terhadap perjanjian Renville yang cenderung merugikan pihak Indonesia, akhirnya mendeklarasikan berdirinya Negara Islam Indonesia (NII). Setelah Soekarno dan Hatta ditangkap di Yogyakarta, sembari terus memukul mundur Belanda, Kartosuwiryo menggangap bahwa kedaulatan Indonesia sudah berakhir dan diganti dengan Republik Indonesia Serikat (RIS) buatan Belanda. Dalam kondisi kekosongan pemimpin ini, Kartosuwiryo ber-ijtihad memplokamirkan NII pada 7 Agustus 1949. Baginya Islam memiliki konsep yang jelas; Islam adalah agama dan negara. Ia juga yakin bahwa untuk menegakkan hukum-hukum Allah di muka bumi maka wajib ada kekuasaan yang menjamin, dan kekuasaan itu adalah pemerintahan Islam. Gerakan yang diluncurkan oleh Kartosuwirjo juga disebut dengan Darul Islam (DI) (3).

Senada dengan hal di atas, Martin van Bruinessen menyebut bahwa embrio gerakan radikalisme Islam di Indonesia bisa dilacak sejak kemunculan Darul Islam (DI)-Negara Islam Indonesia (NII) yang dikomandoi oleh Kartosuwiryo pada era 1960-an. Meski tidak menyebut kelompok-kelompok sebelumnya seperti Al-Irshad dan Persis, namun analisis Martin bukan berarti hanya parsial. Ia kemudian menyebut bahwa pada tahun 19701980-an kekerasan dan aksi terorisme berlanjut dengan skala lebih massif yang oleh media dikaitkan dengan jaringan terorisme bernama Komando Jihad. Salah satu pemimpin kelompok ini mengaku merupakan simpatisan DI dan pernah kontak dengan Ali Murtopo, khususnya dalam memerangi komunisme. Gerakan-gerakan ini menurut Martin terus bergerilya dan mengendalikan beberapa intelijen. Pada awal 1980-an sekelompok kecil mahasiswa di Yogyakarta menerbitkan buletin semi-rahasia yang dengan terang-terangan memamerkan bahwa mereka adalah simpatisan DI. Para editornya kemudian ditangkap dan diadili, tetapi semua jaringan kontak mereka berhasil bertahan dan muncul kembali setelah Suharto lengser. Mereka lalu mendirikan pesantren di Ngruki
Solo, yang dikelola oleh dua orang kiai, Abdullah Sungkar dan Abu Bakar Ba'asyir. Keduanya dikenal baik di kalangan Masyumi/Dewan Dakwah Islamiah Indonesia (DDII) (Abdullah Sungkar sebenarnya adalah ketua cabang Jawa Tengah DDII). Otoritas kedua guru ini sering diuji dan banyak dari rekan-rekan mereka ikut terjun dalam kegiatan Komando Jihad sehingga mengakibatkan hukuman penjara. Setelah bertugas beberapa tahun di tahanan, mereka lantas berlindung ke Malaysia (19).

Pasca Orde Baru runtuh, muncul banyak sekali gerakan Islam gaya baru yang sesungguhnya jika dilacak merupakan anakpinak dan kelanjutan gerakan-gerakan sebelumnya. Peter G. Riddel seperti yang dikutip oleh Sun Choirol Ummah membagi dua kekuatan Islam pascaruntuhnya Orde Baru: liberal-moderat dan radikal atau fundamental. Islam liberal dan moderat dengan penafsiran terbuka terhadap ajaran Islam, sekalipun tidak sama persis, sedangkan Islam radikal atau fundamentalis memiliki paham penafsiran tertutup. Beberapa kelompok Islam seperti Jaringan Islam Liberal (JIL), Lembaga Kajian dan Pengembangan Sumber Daya Manusia (Lakpesdam) NU, Jaringan Intelektual Muda Muhammadiyah (JIMM), adalah beberapa kelompok Islam yang dapat dikategorikan ke dalam kelompok Islam yang beraliran terbuka (27). Sedangkan Front Pembela Islam (FPI), Laskar Jihad, Gerakan Anti Zionis Isreal (GAZA), Gerakan Pemuda Islam (GPI), Majelis Mujahidin, Laskar Hisbullah, Laskar Jundullah, Front Thoriqatul Jihad (FTI), dan Laskar Pembela Islam (LPI) masuk dalam kategori golongan eksklusif-fundamentalis (5).

Hal demikian juga sekaligus menandai lahirnya dunia maya yang menjadi ladang baru untuk menyebarkan ideologi bagi gerakan Islam radikal. Sidney Jones menyebut bahwa bagaimana gerakan ekstremis transnasional mulai mengubah pola gerakan dan rekrutmen dengan memanfaatkan media sosial, seperti Facebook, Twitter dan Whatsapp dan media online lainya. Ia mulai memetakan pola perkembangan gerakan ekstremis sejak periode Jamaah Islamiyah (1999-2003), Noordin M. Top (2004-2009), pasca kampkamp training di Aceh (2010-2013), dan 
yang terakhir masuknya ISIS di Indonesia (2014-2015).

Dari hasi risetnya, Sidney Jones mengatakan bahwa Imam Samudera adalah orang pertama yang berhasil mengobarkan cyber-jihad di Indonesia. Bahkan pernah mendesak Indonesia dan menyeru untuk melakukan jihad, sembari mengajarkan banyak cara untuk melakukannya dari dalam penjara sebelum dieksekusi pada tahun 2008 silam. Ia mulai bergabung dengan jaringan online Jamaah Islamiyah (JI) pada tahun 2000 melalui akun Yahoo.

Pada tahun 2001, Imam Samudra mendirikan sebuah situs web untuk mempromosikan dan mengklaim penghargaan atas operasi Jamaah Islamiyah (JI), termasuk pemboman pada Natal bulan Desember tahun 2000. Situs itu diberi nama tibb.beritaislam.com. Istilah "tibb" merupakan akronim dari Tentara Islam Batalyon Badar; sebuah nama yang merujuk kembali pada salah satu pertempuran besar di awal sejarah Islam. Menurut Jones, situs itu kemudian tidak dibuka lagi dan setelah sekian lama Imam Samudra mendekam di balik jeruji besi, kebanyakan orang Indonesia tidak pernah tahu bahwa ia telah mengaku bertanggung jawab atas serangan pra-Bali, meskipun ia tidak menyebutkan nama JI, tentu saja atas sepak terjangnya di dunia maya.

Setelah itu, ia juga merilis pernyataan pada sebuah situs dengan tujuan untuk pembenaran atas tindakan pemboman Bali tahun 2002 yang diberi nama www.istimata.com. Istimata dicomot dari istilah bahasa Arab yang berarti "tindakan bunuh diri". Deklarasi tersebut menjelaskan bahwa pembom tersebut menggunakan istilah musuh al-Qaeda. "Bagi Anda, tentara salibkafir, jika Anda mengatakan bahwa pembunuhan tersebut ditujukan terhadap warga sipil yang tidak berdosa dari negara Anda, ketahuilah bahwa Anda telah melakukan jauh lebih buruk dari itu. Apakah 600.000 bayi di Irak, setengah juta wanita dan anak-anak di Afghanistan kalian anggap pantas terkena ribuan ton bom Anda?" ujar Imam Samudra.

Imam Samudra ditangkap pada bulan November 2002 dan dijatuhi hukuman mati sepuluh bulan kemudian, namun ia terus menyeru cyber-jihad dari penjara dan beberapa pengikutnya mendirikan situs untuk mempromosikan berita tentang jihad global, kendati kebanyakan dari mereka pada akhirnya berumur pendek. Yang paling profesional adalah www.muharridh.com, yang dipengaruhi langsung oleh unit media al-Qaeda di Pakistan, yang mulai online sekitar bulan April 2004.

Sepak terjang gerakan radikal yang memanfaatkan media daring tidak berhenti sampai di situ saja. Pasca Imam Samudra dihukum mati, muncul generasi-genarasi penerus yang tak kalah radikal. Pada periode 2004-2009, terorisme yang paling terkenal adalah serangan kelompok sempalan Noordin Top: pemboman kedutaan Australia di tahun 2004, bom Bali kedua pada tahun 2005, pemboman yang gagal di Palembang tahun 2008 dan pemboman hotel 2009 di Jakarta. Pada tahun 2005 muncul juga situs bernama anshar.net. Situs ini menyebarkan doktrin jihad, di bawah manhaj (metode): materimateri pemboman Bali yang pertama, nasihat dari Mukhlas (satu dari tiga pembom Bali), dan alasan mengapa Muslim harus melakukan jihad daripada hanya dudukduduk membicarakannya. Sedangkan satu tahun berikutnya (2006) ada beberapa situs ekstremis penting yang muncul dengan tujuan membangkitkan antusiasme untuk berjihad. Mereka adalah www.arrahmah.com dan www.muslimdaily.net. Keduanya dikelola oleh pria dengan pengalaman internasional bernama Muhammad Jibril (pernah belajar di Karachi) dan Abdul Rahim Ba'asyir, putra bungsu Abu Bakar Ba'asyir yang pernah belajar di Pakistan dan Yaman. Dalam hal afiliasi organisasi, Jibril berasal dari keluarga JI namun ia dan ayahnya lebih terkait dengan Majelis Mujahidin Indonesia, organisasi advokasi pro-syariah yang didirikan pada tahun 2000 oleh Abu Bakar Ba'asyir dan Irfan Awwas, Paman Jibril. Muslimdaily.net sepertinya lebih mewakili kepentingan keluarga Ba'asyir dan komunitas Ngruki (15).

Pada kurun waktu itu (2004-2009) Sidney Jones menilai bahwa penggunaan internet meningkat secara dramatis namun sebagian besar pengguna - sekitar 60 sampai 70 persen-masih mengandalkan warnet. Dalam beberapa kasus, ekstremis menjalankan aksinya, terutama di daerah Solo, Jawa Tengah. Beberapa server mereka 
beralih ke mode komunikasi baru, pertama melalui internet relay chatting (MIRC), kemudian melalui forum yang dilindungi kata sandi yang terkait dengan situs web tertentu. Sebagian juga membuka jalan ke berbagai layanan Blackberry Messenger (BBM) dan Yahoo Messenger. Yang terakhir mereka mendapat keuntungan lantaran bisa saling bertatap muka melalui video. Beberapa jihadis juga menganggapnya lebih aman daripada via teks biasa. Sepanjang periode ini, ditandai dengan tingginya tingkat aktivisme jihad di Indonesia dan munculnya teknologi baru yang lebih canggih. Pun tidak ada bukti nyata bahwa perekrutan jihad yang signifikan terjadi secara online. Kebanyakan dari mereka masih bertemu dalam sesi ceramah atau diskusi kelompok di masjid atau sekolah dan baru kemudian ditindaklanjuti dengan chatting di internet. Dalam beberapa kasus, mereka bersaut sapa di chat online dan kemudian memutuskan untuk bekerja sama, namun sisi kerahasiaan gerakan jihad terselubung ini membuatnya cepat berkembang dalam spektrum yang luas (15).

Pada tahun berikutnya, tepatnya 2010 muncul forum jihad baru bernama Forum Jihad al-Busyro, yang misinya melanjutkan jihad online Jihat al-Tawbah. Terinspirasi oleh gagasan "jihad individu", forum jihad online itu dinisiasi oleh Arif Wicaksana Aji alias Hendro. Ia adalah alumnus pesantren alMukmin, Ngruki, Solo tahun 2005, dan dinikahkan kepada putri gurunya, Afief Abdul Madjid, setahun setelah lulus. Kemudian ia kembali ke kampung halamannya di Kalimantan Selatan, yang secara fisik terisolasi dengan sesama penggemar jihad. Dalam berbagai hal, ia sangat terobsesi dengan internet sehingga teman-temannya menyebut komputernya sebagai istri kedua dan memberinya julukan Hendro Laptop. Ia bertekad untuk membuka kelompok diskusi baru tentang jihad, menjadi penjaga gawang al-Busyro yang proses rekrutmen anggotanya diseleksi dengan hatihati. Namun ia kemudian menggunakan blognya, al-ansar007.blogspot.com, untuk mendistribusikan materi jihad kepada khalayak yang lebih luas. Ia ingin mengampanyekan "jihad open source" yang bisa diakses siapa saja, sama seperti majalah online Al-Qaeda di Jazirah Arab. Hal ini juga mendorongnya kembali ke tujuan awal anshar.net: menjadi semacam toko serba ada yang memuat berita, laporan jihad dan semua instruksi-instruksi militer di semua tempat yang sama.

Salah satu dampak atas tindakan Hendro salah satunya bisa dilihat dari merebaknya efek ideologisasi di kalangan remaja dan mahasiswa. Penelitian LaKIP (Lembaga Kajian Islam dan Perdamaian), seperti yang dikutip Agus SB, pada tahun 2010 mengungkap bahwa 48,9\% responden yang terdiri dari pelajar SMA se-Jabotabek menyatakan setuju dengan gagasan dan aksi radikalisme agama. Bahkan sejumlah kampus juga menyiratkan fenomena serupa. Riset ini mengambil sampel 2.466 mahasiswa sejumlah kampus ternama di Indonesia. Hasilnya 65\% (1.594 responden) setuju dengan aksi sweeping sejumlah organisasi massa (ormas) yang mengatasnamakan agama (2).

\section{d. Lenyapnya Etika Diskursus}

Ada banyak kasus tentang hilangnya etika diskursus dalam ruang publik dunia maya. Bagian ini penulis sengaja menyuguhkan beberapa kasus besar sepanjang tahun 2017-2018 yang sempat menghebohkan jagat dunia maya yang berujung kepada gerakan-gerakan massa.

Pertama adalah kasus Ahok yang bermula dari sebuah potongan video pidatonya di Kepulauan Seribu pada September 2016 yang tersebar di dunia maya. Ahok berkunjung ke Kepulauan Seribu untuk mensosialisasi program budi daya ikan kerapu. Namun, lidah Ahok selip saat berpidato dengan menyitir ayat alQur'an surat Al-Maidah ayat 51. Dari 40 menit durasi pidato Ahok, potongan video sepanjang 13 detik ini kemudian diperdebatkan (30). Adalah Buni Yani, aktor di balik pengeditan video tersebut.

(r)

za wahyudi 2 tahun yang la

mudah2an nyawa orang soplak ini..cepat2 di cabut malaikat maut.. biar tahu rasa..azab kubur buat si kafir ini... semoga mendapat lalnat Allah SWT. AAMIIN

$14 \%$ BALAS

Lihat 10 balasan $\vee$

(G)

oes 772 tahun yang lalu

Yg Bodoh itu orang Islam DKI knp masih pilih AHOK. ."

$18 \%$ BALAS

Litat 16 balasan 4

(3) dega agus 2 tahun yang lalu

olong pak ahok!! bapak harus berfikir dulu sebelum berbicara. saya tidak dari jakarta ak, tapi saya muslim. secara tidak langsung bapak sama saja mengatakan kitab suci kami bohong"

apak kalau mau jadi gubernur, silahkan pak... tapi tolong jgn hina kitab suci kami pak Baca selengkapnya 
Gambar di atas merupakan screenshot komentar di akun Youtube anonim "Katakan yang Benar" yang mengunggah potongan video Ahok berdurasi 41 detik dengan narasi judul, "Kurang Ajar!!! Ahok Menghina AlQur'an, Ini Baru Namanya Sara, Rasis, Penghinaan Agama," tertanggal 5 Oktober 2016 (31). Untuk lebih jelasnya silakan lihat screenshot di bawah ini:

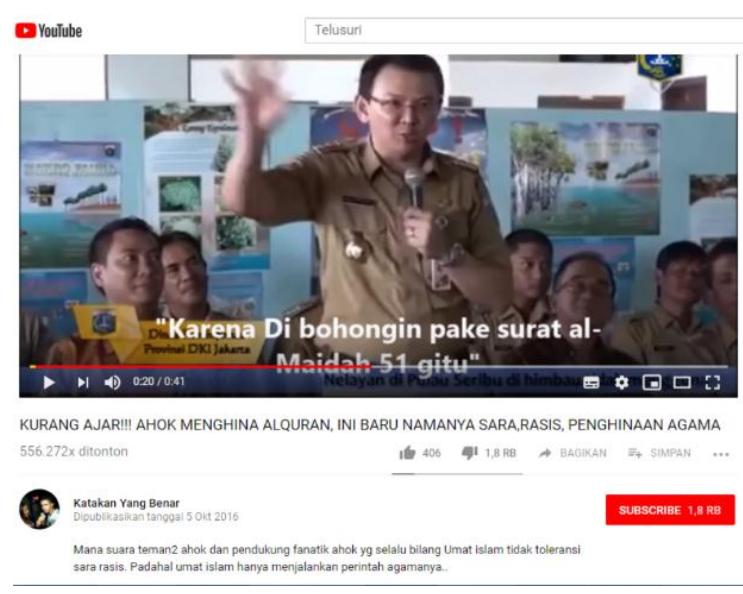

Akun di atas dengan narasi judul yang menohok coba membangun opini publik dengan wacana bahwa Ahok adalah penghina al-Qur'an. Padahal jika diamati dengan saksama video full durasinya, konteks dari sambutan itu bukan semata-mata untuk menista al-Qur'an melainkan mengingatkan bagaimana politisi seringkali menggunakan legitimasi kitab suci untuk menjatuhkan lawan politiknya terutama mereka yang berlatar belakang non Muslim.

Hal demikian, salah satunya ditegaskan oleh Pakar Tafsir UIN Sunan Kalijaga, Sahiron Syamsuddin. Dalam wawancari dengan media massa, Sahiron mengatakan bahwa Ahok tak menyebut nama ulama tertentu, jadi tidak menodai. Ahok menurut Sahiron, mengkirtik politisi yang memanfaatkan ayat Al-Maidah 51 untuk kepentingan kekuasaannya. Sahiron menganggap, dalam memahami surat $\mathrm{Al}-$ Maidah ayat 51, harus memperhatikan aspek bahasa, sejarah, dan pesan utama ayat tersebut. Dari sisi bahasa, aulia bukan pemimpin, tetapi lebih kepada teman setia. Ia merujuk pada sebuah fatwa di Mesir. Masyarakat negara tersebut yang berpenduduk mayoritas Muslim dan memiliki konstitusi yang jelas bisa memilih pemimpin non Muslim bahkan perempuan (32).
Jika merujuk kepada konsepsi etika diskursus Habermas maka apa yang diberitakan tentang Ahok tidak benar, tidak jujur dan tidak tepat.

Pertama, ketidakbenaran terletak pada tuduhan bahwa Ahok menista ayat suci alQur'an. Karena konteks pidatonya itu sama sekali tidak bermaksud seperti itu, redaksi yang benar adalah, "jangan mau dibohongi pakai surat al-Maidah 51".

Kedua, ketidakjujuran terletak pada menafikan fakta yang sesungguhnya bahwa potongan video itu digunakan untuk medeligitimasi Ahok dalam kontestasi Pilgub DKI Jakarta 2017, padahal video itu direkam pada tahun sebelumnya. Kalau memang Ahok menista lantas kenapa video itu baru dipermasalahkan satu tahun berikutnya, menjelang Pilgub DKI Jakarta?

Ketiga, ketidaktepatan terletak pada argumentasi yang dibangun bahwa non Muslim dilarang menjadi seorang pemimpin. Padahal makna tafsir auliya bukanlah semata merujuk kepada pemimpin melainkan juga teman setia.

Dengan demikian akun "Katakan yang Benar" beserta komentar-komentarnya melenyapkan etika komunikasi karena ketiga klaim validitas di atas sama sekali tidak ada.

Kedua adalah kasus pembakaran bendera HTI di Garut saat pagelaran Hari Santri Nasional (HSN) 22 Oktober 2018 lalu. Saat video berdurasi 7 menit 12 detik itu tersebar secara terstruktur dan massif "perang wacana" di dunia maya pun berlansung bombastis.

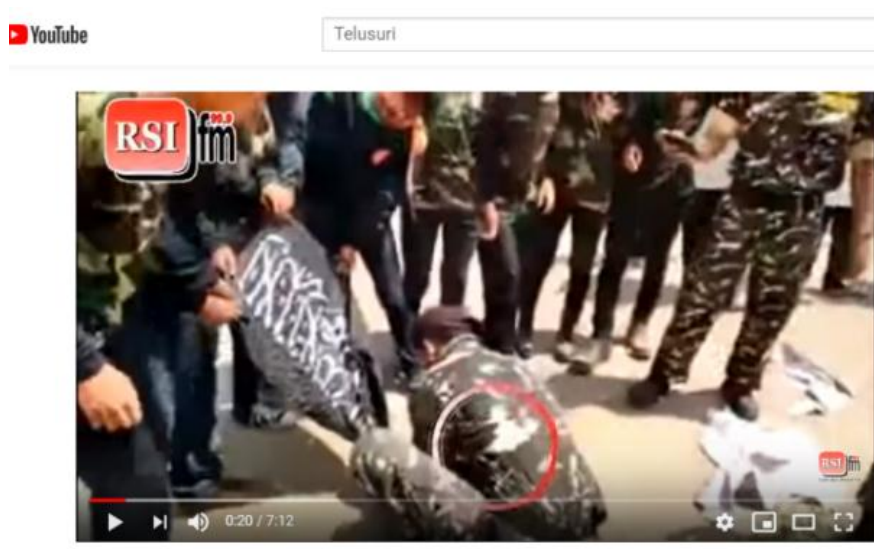

*Banser ZKolimatTounid NASIFM

Anggota Banser Membakar Kalimat Tauhid, Ini Kata Para Ulama $2.328 \times$ ditonton

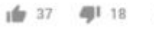


Video yang diunggah oleh akun RSIfm di atas dari redaksi judulnya saja sudah menimbulkan kejanggalan. "Pembakaran bendera" dipelintir menjadi "pembakaran kalimat tauhid" dan untuk melegitimasi mereka mencatut pendapat para ulama. Yang lebih ironis adalah komentar-komentar netizen sebagaimana screenshot di bawah ini:

83

d dry 3 minggu yang lau

Baru di rezim plongo dan lucuzan bisa kayak gin

Mezm bobrok, inikahsatpam penjaga gereja kalian bong

denganut ajaran abu janda

7 Balas

2. Ami Ansyah 3 minggu yang lalu

Nauzubillah., adakah para guru para kiyai di situ. sehingga perbuatan biadab itu di pertontonkan depan santri.. laknatullah

If 8 a galas

(2)

Bubarin banser gk ielas, pembubar pengajian peniaga gereja

16. 7 BALAS

P. Abangtanu Gumala 3 minggu yang la

kelakuanya seperti iblis. apapun alasannya.tunggu Azab Allah akan segera menimpa kalian semua. Amin Amin Amin insyaallah

I1. 9 BALAS

that 3 balasan $y$

Minang kabau 3 miningou yang laiu

Oi Padang kami tauhil udah ada dari dulu . kenapa di Jawa di bakar lambang Tauhid... kami oran tu emang Islam tapi Islam pengakuan ... yang ngak suka bis komen saya :

Tren di Media Online dan Twitter

Media Online aktif mengangkat isu RS, di Medsos isu Pembakaran Bendera berjaya
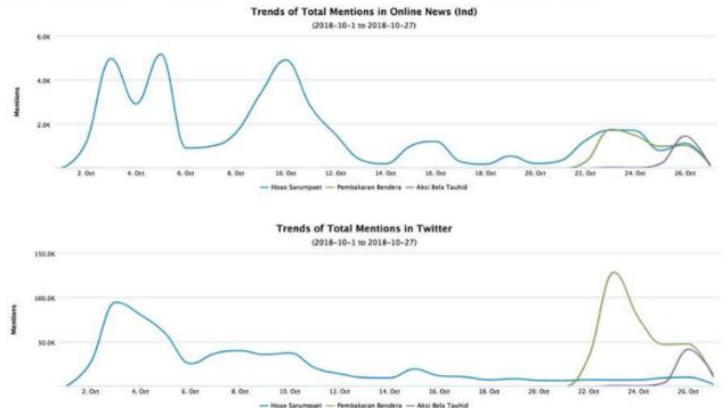

Komentar-komentar di atas adalah produk mediatisasi agama yang pada akhirnya melahirkan bahaya medsos "echo chamber". Istilah ini merujuk pada situasi di mana keyakinan diperkuat oleh komunikasi dan pengulangan-pengulangan dalam sistem tertutup. "Echo chamber" adalah ruang gema yang berisi keseragaman pandangan dan kemanunggal-an selera sehingga tak menghasilkan dialog yang baik. Hal demikian menurut penulis juga ikut menyuburkan tumbuhnya post-truth alias zaman yang tak begitu mementingkan lagi sebuah kebenaran.

Situs DroneEmprit dalam hal ini mampu merilis hasil analisis yang sangat bagus mengenai sumber hoaks dan rentetan meta-narasi yang sengaja dibuat untuk membentuk wacana ataupun meng-counter- nya. Dengan mengunggah catatan bertajuk "Magnitudo Percakapan Pembakaran Bendera Mengalahkan Hoaks Sarumpaet", situs tersebut berhasil menelisik darimana asal hoaks, akun siapa saja yang "bermain" baik yang pro maupun kontra dengan berbasis pada medsos Twitter dan Instagram.

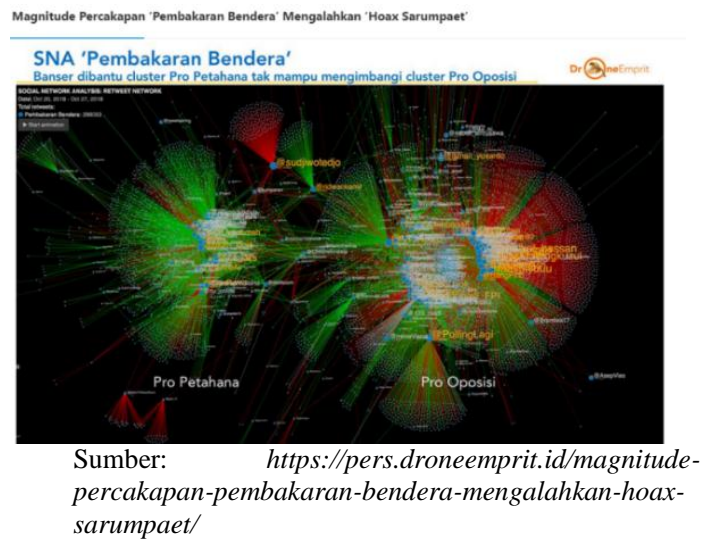

Dari hasil analisisnya, situs tersebut menyatakan bahwa puncak percakapan tentang Ratna Sarumpaet (RS) terjadi pada tanggal 3 Oktober, dengan total 108k mentions. Selanjutnya, isu RS ini turun tetetapi masih sangat tinggi volumenya. Setelah hampir sebulan, percakapan masih lumayan berlangsung, tak pernah sepi, seolah sedang dipertahankan selama mungkin.

Sedangkan percakapan tentang pembakaran bendera, puncaknya terjadi pada 23 Oktober, dengan total 133k mentions. Ternyata ini melebihi puncak percakapan tentang RS. Padahal isu RS saat itu tengah menjadi isu yang luar biasa besar dengan pemberitaan di TV dan berbagai media online yang sangat masif.

Hanya berselang 5 hari, total volume percakapan tentang pembakaran bendera sudah sangat tinggi, yaitu 356k mentions. Jika dibandingkan dengan total untuk RS selama hampir sebulan sebanyak 680k mentions, isu bendera ini telah mencapai separuh lebihnya. 


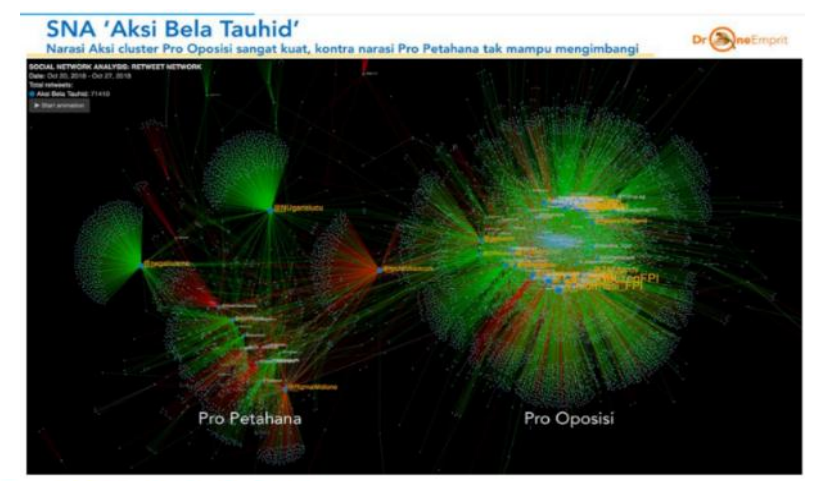

Tren di Media Online dan Twitter

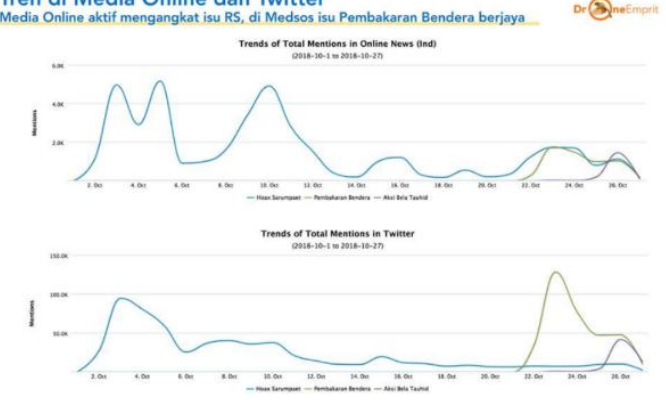

Dalam peta Social Network Analysis (SNA) tentang pembakaran bendera, dapat dilihat ada dua klaster besar. Yang paling besar adalah dari klaster pro oposisi, dan klaster pro petahana lebih kecil. Hal ini menunjukkan, dalam "perebutan wacana" tentang bendera, Banser meski sudah didukung oleh klaster pro petahana, belum bisa mengimbangi suara sebagian umat Islam yang didukung oleh klaster pro oposisi.

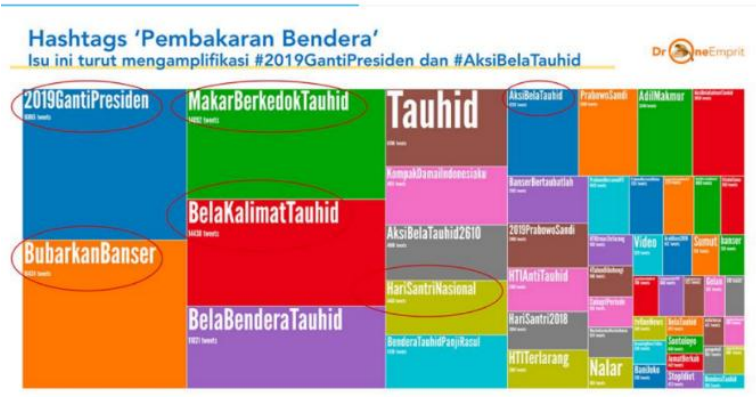

Kontra narasi yang dibangun oleh klaster petahana dalam menghadapi Aksi Bela Tauhid adalah dengan membangun hestek \#PrabowoBersamaHTI. Isu pembakaran ini akhirnya masuk ke ranah politik, karena oposisi sudah terlebih dahulu membawa hestek politik \#2019GantiPresiden dalam narasi mereka tentang pembakaran bendera ini. Dan sebagai balasan atas hestek petahana itu, kubu oposisi kemudian membuat hestek tandingan \#PrabowoBersamaUlama.
Data yang didapat DroneEmprit memperlihatkan betapa kuatnya magnitude isu pembakaran bendera, yang bahkan bisa mengalahkan magnitude "gempa" RS. Ini berarti, isu terkait agama, kalimat tauhid, harus disikapi dengan sangat hatihati dan serius.

Salah satu faktor yang sangat berpengaruh terhadap ekskalasi isu ini adalah kontra narasi yang disampaikan oleh Banser melalui ketua umum GP Ansor bahwa apa yang dilakukan oleh oknum pembakar bisa dimaklumi karena bendera yang dibakar adalah bendera HTI. Di sisi lain, sebagian umat Islam yang protes tidak melihat itu bendera apa. Yang mereka lihat adalah di dalam bendera itu ada kalimat Tauhid, yang tidak semestinya dibakar begitu saja.

Kedua argumen yang sama-sama kuatnya ini, dan diyakini kebenarannya oleh masing-masing kubu, telah menghasilkan benturan opini yang sangat massif. Turut sertanya MUI dan Muhammadiyah dalam memberi pernyataan, yang menyarankan agar Banser meminta maaf, semakin memperkuat narasi dari umat. Di sisi lain, keluarnya pernyataan dari PBNU yang menyesalkan pernyataan dari MUI dan Muhammadiyah, juga memperkuat narasi dari Banser. Polisi dan media-media TV juga membangun narasi yang sama dengan Banser bahwa itu adalah bendera HTI.

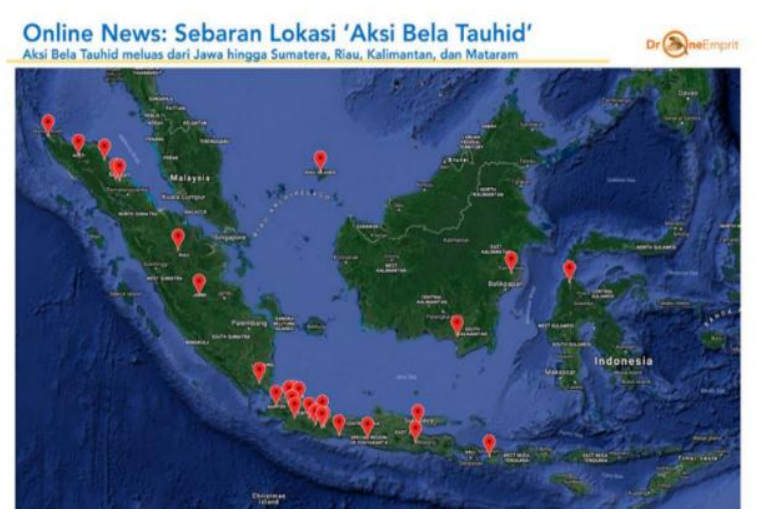

Apakah percakapan di media sosial di atas berdampak di dunia nyata? Dari peta geografis tentang sebaran lokasi Aksi Bela Tauhid yang diekstrak oleh situs ini dari pemberitaan media online membuktikan bahwa, percakapan di media sosial bisa sangat berpengaruh pada kejadian di dunia offline (nyata). Sebaran video pembakaran di media sosial, 
perdebatan yang terjadi di sana, ternyata menjadi percakapan offline yang berhasil menggerakkan demo di berbagai titik di hampir seluruh Indonesia dalam waktu 4 hari saja (28).

Jika kembali kepada kasus tersebarnya video pembakaran tadi dapat disimpulkan bahwa pemelintiran redaksi dari "Bendera HTI ke Bendera Tauhid" adalah awal mula meletupnya berbagai kericuhan baik di dunia maya dan nyata. Unggahan video itupun pada akhirnya ditarik ke ranah politik yang muaranya adalah pertarungan Pipres 2019.

Jika menggunakan kacamata kritis maka meta-narasi itu tidaklah muncul begitu saja (taken for granted) dari ruang yang hampa. Siapakah yang membakarnya? Di mana tempat pembakaran itu? Bendera itu milik siapa? Siapa yang menyebarkan video itu? Dan sebentar lagi akan ada momentum apa?

Pertama, seandainya pembakaran bendera itu dilakukan bukan oleh Banser tentu perkaranya bisa jadi berbeda.

Analoginya seperti digambarkan oleh Ahmad Zainul Hamdi di laman status Facebook-nya seperti ini: Ada sebuah organisasi berlambang palu dan sabit, saat saya membakarnya tak lantas saya menjadi orang yang mengharamkan menggunakan kedua benda itu. Apalagi profesi saya adalah petani. Saya membakarnya karena luapan bentuk kegeraman dalam sebuah pertarungan ideologi yang terbuka.

Artinya karena Banser bagian dari NU dan sekarang mantan Rais Aam PBNU sedang berkontestasi menjadi calon Wakil Presiden pada Pilpres 2019 maka semua hal yang berkaitan dengan NU bisa dijadikan delegitimasi yang ujung pangkalnya adalah memberikan citra buruk bahwa NU beserta semua banomnya adalah ormas yang menista agama atau kalimat tauhid. Sehingga animo masyarakat untuk memilihnya memudar, bahkan harapannya adalah membubarkan ormas dengan anggota terbesar se-dunia itu.

Kedua, pelaksanaan HSN itu bukan tanpa sengaja memilih tempat di Kabupaten Garut Jawa Barat. Sebab Jawa Barat, termasuk Kabupaten Garut merupakan basis konstituen dari Kubu Prabowo pada Pilpres 2014. Dari rekapitulasi KPU, Pasangan PrabowoHatta menang di 22 kabupaten/kota di Jabar. Sementara itu, Jokowi-JK hanya unggul di empat kabupaten/kota di Jabar, yakni Kabupaten Subang, Kabupaten Indramayu, Kabupaten Cirebon, dan Kota Cirebon (16). Maka dengan menggelar HSN di sana sama saja dengan "mengejek" kubu lawan. Dengan demikian, tak aneh bila peringatan HSN adalah bagaimanapun caranya harus dicari titik lemahnya agar bisa dijadikan isu tandingan.

Ketiga, bendera yang seringkali diklaim sebagai bendera panji zaman Rasulullah itu diakui atau tidak merupakan simbol dari bendera Hizbut Tahrir Indonesia (HTI). Oleh karena itu, terlepas kecerobohannya, Banser dengan segala bentuk doktrinasi ideologi organisasinya memilih untuk membakarnya karena bendera itu adalah simbol ormas terlarang. Seandainya, yang dikibarkan bukan bendera semacam itu tentu saja tidak mungkin akan ada insiden pembakaran. Dalam konteks perebutan wacana, tentu saja apa yang dilakukan Banser adalah sebuah blunder dan tindakan yang ceroboh.

Keempat, jika dilihat dari pilihan redaksi judul di akun Youtube RSIfm terdapat keberpihakan dan nada provokasi. Redaksi judul yang dipilih, seolah sesuai dengan akun-akun yang beroposisi dengan NU. Padahal radio tersebut adalah radio kampus STMIK-AMIK Dumay yang seharusnya bisa lebih netral sebagai bagian dari organisasi intra kampus.

Kelima, dari sekian rententan peristiwa itu sebetulnya muaranya hanya satu: Pilpres 2019. Merapatnya Jokowi ke kubu NU, dan Prabowo ke PKS beserta afiliasinya semakin mempertegas polarisasi antara Islam Kanan-nasionalis dengan moderat-nasionalis. Maka apa pun yang bisa dipelintir menjadi isu berkaitan dengan dua ormas keagamaan itu adalah hal menguntungkan bagi masing-masing kubu.

Jika dikaitkan dengan etika diskursus Habermas maka narasi judul berita dalam video tadi mengalami kematian rasionalitas komunikatif karena tidak 
adanya etika diskursus; kebenaran, ketepatan dan kejujuran.

Ketidakbenaran tampak pada pernyataan bahwa anggota Banser membakar kalimat tauhid. Padahal yang ia bakar adalah bendera salah satu ormas terlarang yang kebetulan bersimbol kalimat tauhid. Sehinggal klaim validitas kebenaran tidak berlaku dalam hal ini.

Kemudian ketidaktepatan juga tampak pada pernyataan bahwa para ulama ikut mengecam tindakan tersebut. Yang mereka maksud ulama itu siapa? Ulama yang bisa diterima semua kalangan atau ulama dari kelompok tertentu? Padahal syarat dari klaim validitas ketepatan adalah intersubyektivitas masyarakat umum bukan semata golongan saja. Seharusnya ada juga pihak dari ulama NU yang dimintai keterangan pendapat, baik yang pro maupun kontra agar pernyataan tersebut tak terkesan tendensius sekali.

Yang terakhir ketidakjujuran. Bahwa gelombang protes terhadap tuduhan penistaan kalimat tauhid itu faktanya bernuansa politik bukan murni atas dasar kesadaran agama. Puncaknya adalah muncul gelombang massa aksi bela tauhid yang dalam praktiknya ditunggangi oleh salah satu kubu kontestan Pilpres 2019.

Dengan demikian, dalam kasus kali ini, konsensus untuk saling memahami tidak terwujud lantaran terdapat komunikasi yang terdistorsi secara sistematis. Baik kubu yang membakar maupun yang dibakar mengalami apa yang disebut Marx sebagai falsches Bewußtsein (kesadaran palsu). Mereka sebetulnya memahami bahasa dan perilakunya, tetetapi tidak sadar bahwa mereka telah waham satu sama lain sehingga tuturan dan perilakunya tidak dihasilkan oleh akal sehat, melainkan dari efek indoktrinasi ideologis.

\section{Kesimpulan}

Sebagai anak dari revolusi digital, media sosial adalah sebuah bentuk kemajuan telekomunikasi. Kehadirannya adalah untuk memperluas ruang publik demokratis yang terbatas pada sekat komunikasi konvensional. Namun akibat dari dominasi kelompok tertentu, ruang publik demokratis tersebut berubah menjadi gelanggang saling caci dan delegitimasi. Munculnya aksi 212, bela tauhid adalah buah dari kemarahan komunikasi digital

Dengan demikian maka dapat ditarik kesimpulan bahwa perebutan wacana dalam ruang publik (public sphere) dunia maya selain faktor kemajuan teknologi juga dipengaruhi oleh politik, lebih tepatnya politisasi agama yang muaranya adalah Pilpres 2019. Ruang publik yang seharusnya menjadi lokus diskusi argumentatif yang rasional pada akhirnya menjadi ruang intimidasi dan dominasi yang monologis sehingga menghilangkan karakter publiknya. Dalam hal ini, konsensus saling memahami tidak berlaku lagi akibat dari komunikasi yang terdistrosi.

\section{References}

1. Abdullah MA. Pendidikan agama era multikultural-multireligius. Cet. 1.

Jakarta: Pusat Studi Agama dan

Peradaban Muhammadiyah, 2005.

2. Agus S Bakti. Deradikalisasi Dunia Maya: Mencegah Simbiosis Terorisme dan Media. Jakarta: Daulat Press, 2016.

3. Al-Chaidar. Pengantar Pemikiran Politik Proklamator Negara Islam Indonesia S.M. Kartosoewirjo. Darul Falah, 1999.

4. Alimi Moh Yasir. Mediatisasi Agama Post-Truth dan Ketahanan Nasional. Yogyakarta: LKiS, 2018.

5. Alkaf H. Quo Vadis Liberalisme Islam Indonesia. Jakarta: Kompas, 2011.

6. Astuti YD. Peperangan Generasi Digital Natives Melawan Digital Hoax Melalui Kompetisi Kreatif. INFORMASI 47: 229-242, 2017.

7. Casanova J. Public Religions in the Modern World. University of Chicago Press, 1994.

8. Fakhruroji M. Komodifikasi Agama Sebagai Masalah Dakwah [Online]. Ilmu Dakwah: Academic Journal for Homiletic Studies 5: 1-18, 2010. 
9. $\quad$ Franz MS. 75 Tahun Jürgen Habermas. Basis 11-12 Tahun Ke 53: 2004.

10. Hardiman BF. Demokrasi Deliberatif: Menimbang 'Negara Hukum' dan 'Ruang Publik' dalam Teori Diskursus Jürgen Habermas. Yogyakarta: Kanisius, 2009.

11. Hardiman FB. Menuju Masyarakat Komunikatif; Ilmu, Masyarakat, Politik, Dan Postmodernisme Menurut Jurgen Habermas. Yogyakarta: Kanisius, 2013.

12. Hardiman FB. Seni Memahami, Hermeneutik Dari Schleiermacher Dampai Derrida. Yogyakarta: Kanisius, 2015.

13. Hasan MI. Pokok-Pokok Materi Metodologi Penelitian dan Aplikasinya. Bogor: Ghalia Indonesia, 2002.

14. Iswara N. Raditya. (Bukan) obor rakyat: dokumentasi yang terstruktur, sistematis, dan masif mengenai fakta nyeleneh Pilpres 2014. Cetakan pertama. Gejayan, Yogyakarta: Media Pressindo, 2014.

15. Jones S. Online Activism and Social Media Usage Among Indonesian Extremists. Institute for Policy Analysis of Conflict (IPAC) Report 24, 2015.

16. Juditha C. Interaksi Simbolik dalam Komunitas Virtual Anti Hoaks untuk Mengurangi Penyebaran Hoaks [Online]. Jurnal Penelitian Komunikasi dan Pembangunan 19: 17-32, 2018.

17. K. Denzin N, S. Lincoln Y. Handbook of Qualitative Research. Yogyakarta: Pustaka Pelajar, 2009.

18. KOMINFO P. Penebar Hoax Bisa Dijerat Segudang Pasal [Online]. Website Resmi Kementerian Komunikasi dan Informatika RI: 2018. https://kominfo.go.id:443/content/detail /8863/penebar-hoax-bisa-dijeratsegudang-pasal/0/sorotan_media [13 Nov. 2018].
19. Martin van Bruinessen. Genealogies of Islamic Radicalism in Post-Suharto Indonesia. South East Asia Research 10: 117-154, 2002.

20. Moyser G, Moyser P of PSG. Politics and Religion in the Modern World. Routledge, 2002.

21. Nugroho A. The Analysis Of Hoax Spread In Social Media [Online]. IOSR Journal Of Humanities And Social Science (IOSR-JHSS) 23: 50-60, 2018.

22. Oetama J. Menegakkan Kebebasan Berekspresi, Berbicara dan Kebebasan Pers. Amir Effendi Siregar. Mengawal Demokratisasi Media: Menolak Konsentrasi, Membangun Keberagaman. Jakarta: Buku Kompas, 2014.

23. Rivers WL. Media Massa dan Masyarakat Modern. Jakarta: Kencana Prenada Media Group, 2003.

24. Steinhoff $\mathbf{U}$. The Philosophy of Jürgen Habermas: A Critical Introduction. OUP Oxford, 2009.

25. Syahputra I. Penggunaan Media Sosial Dan Kemarahan Religius Dalam Kasus Pembakaran Vihara Di Kota Tanjung Balai, Indonesia. Epistemé: Jurnal Pengembangan Ilmu Keislaman 13: 149-172-172, 2018.

26. Umam S. Radical Muslims in Indonesia: The case of Ja'far Umar Thalib and the Laskar Jihad [Online]. Explorations in Southeast Asian Studies 6: 1-26, 2006.

27. Ummah $\mathbf{S}$ c. Akar Radikalisme Islam Di Indonesia. HUMANIKA 12, 2012.

28. Magnitude Percakapan 'Pembakaran Bendera' Mengalahkan 'Hoax Sarumpaet' [Online]. Drone Emprit Publications: 2018. https://pers.droneemprit.id/magnitudepercakapan-pembakaran-benderamengalahkan-hoax-sarumpaet/ [13 Nov. 2018]. 
29. Catat, Ini Hukuman Pidana bagi Pelaku SARA dan Hate Speech - Nasional Tempo.co [Online]. 2018. https://nasional.tempo.co/read/757667/ catat-ini-hukuman-pidana-bagi-pelakusara-dan-hate-speech [13 Nov. 2018].

30. Ini Perbedaan Ahok dengan Buni Yani Setelah Divonis - Nasional Tempo.co [Online]. 2018.

https://nasional.tempo.co/read/1033813 /ini-perbedaan-ahok-dengan-buni-yanisetelah-divonis/full\&view=ok [13 Dec. 2018].
31. Kurang Ajar!!! Ahok Menghina Alquran, Ini Baru Namanya Sara,Rasis, Penghinaan Agama [Online]. https://www.youtube.com/watch?v=Od 83ru80UN8 [13 Dec. 2018].

32. Harapan Mantan Staf Basuki Tjahaja Purnama Setelah BTP Bebas - Nasional Tempo.co [Online]. https://nasional.tempo.co/read/1166735 /harapan-mantan-staf-basuki-tjahajapurnama-setelah-btp-bebas [14 Dec. 2018]. 